\title{
Sovereignty in Rousseau: from Instinctive Freedom to Conscious Freedom
}

\author{
Baltazar Macaíba de Sousa \\ Associate Professor \\ Department of Social Sciences \\ Center for Applied Sciences and Education \\ Federal University of Paraiba \\ Gleidimar Alves de Oliveira \\ Philosophy Teachers and Scholars Association \\ Socialist Thought Studies Center
}

\begin{abstract}
The text is a reading piece about Rousseau's concept of sovereignty, as a maximal expression of men's free willing in the civil society, in a direct relation with the instinct of liberty - will - of men in the natural society. Rousseau was deeply worried about inequality among men, since its consequence is freedom and utmost good inhibition. So, in the transition between wild to political stage, man has preserved and changed his particularity as a free Being. One can affirm that Rousseau started a new moment over sovereignty in which people are the collective being of this supreme will. This is to say that Civil State is a being of reason and, only rational Will can create it. The state appears as a real entity, not an abstract one.
\end{abstract}

Keywords: Sovereignty; Will; freedom; civil society; inequality.

\section{Introduction}

Rousseau's idea of sovereignty demands a study of his work, The Social Contract - or Principles of the Political Right, written in 1757, specifically Book II, which exposes sovereignty as a general will exercise. This way, the formulated hypothesis consists in that sovereignty should not be restricted to The Social Contract, as the basis for its formulation is found in the "Discourse on the sources and fundamentals of inequality among men", 1755. There, according to Bobbio (1987), Rousseau advocates that in the state of nature, man is happy because there is no power outside him and, only with the appearance of private society, he reaches the state of corruption, marked by exacerbation and perversion of "egotistical instincts". Let us see as Bobbio clarifies the concept of the state of corruption: "This state of corruption is called societé civile by Rousseau" (1987,p.48). The state of corruption is a sort of political society in its degenerated condition, but it is distinct from the state of nature, because it is presented under the "corrupted form of the strong over the weak, of rich over poor, the smart over the naives" (Bobbio, 1987,p.48). It was instituted, according to Rousseau, at the time when:

The first man who, having fenced a piece of land, said: "this is mine", because ordinary people believed him. He was the true founder of civil society. How many crimes, wars, murders, misery and horrors would not have been spared to human beings, if that man, by crashing fences, filling ditches, had yelled to his likes:"protect yourselves from this impostor; you will be lost if you forget the fruits belong to everyone, and land is not anyone's.(Rousseau, 1973,p.265).

Man must get rid of this state of corruption, by founding a society based on a pact, because he is born free. Here, we start to expose the fundamentals of Rousseau's sovereignty, whose primary goal is to establish the legitimate structures of the transition from natural to conventional liberty. Thus, the social contract is not institutional and formal; it has a symbolic value, but its clauses are determined in practice, by the nature of the act, so recognized and maintained. The social contract, (legitimate pact) is in search of a society - association - that defends and protects the individual and his assets and all common power, by which (by common force - moral laws and norms) each one, by uniting to all, just obeys himself, remaining so free as before (by suppressing and surpassing his needs).

\section{The Sui generis Character of Sovereignty in Rousseau}

Such Rousseau's principles about sovereignty are in opposition to liberal and jusnaturalist tradition of the State, about which one can summarize: Jean Bodin introduces modern reflections about the State's sovereignty, and the sovereign power attributed to the King to interpret as well as obey laws; sovereignty would be materialized in the sovereign power. 
As to Hobbes, sovereignty is also manifested in the absolute power of the State, in order to free man from the permanent state of war. In Locke, the State and sovereignty emerge from contract (pact); sovereignty is not present in the sovereign power of the King, but in the contract, so much so that he is subjected to the laws of the Parliament. One can affirm that Rousseau started a new moment over sovereignty in which people are the collective being of this supreme will. This is to say that Civil State is a being of reason and, only rational Will can create it. The state appears as a real entity, not an abstract one. Therefore, not to recognize this quality is to fall into individualist selfishness and not to overcome the state of corruption.

At what time does sovereignty appear to Rousseau? When the transition from natural to conventional freedom occurs, interpreted as a political problem both at the moral and the rational levels, for the social order is a sacred right, above the individual, although it is processed within man: transfiguration to the social. The "social order" is a right that stems from conventions, in the consciously and voluntarily organized society, as according to Rousseau, man is characterized by free will. This is the condition for men to form a legitimate pact, in order to recover their freedom and equality. It lies in an association act understood as a reciprocal commitment between the public and the private, each individual pledging himself to a dual relationship: as a member of the sovereign body towards the private ones, as well as a member of the State towards the sovereign. See how Rousseau clarifies his understanding of inalienable sovereignty and who the sovereign is:"I declare that, if sovereignty is not but a general will exercise, will never be alienated; and that the sovereign, who is just a collective entity, can only be represented by himself. Power can be transferred, not the will" (Rousseau,1973,p.49-50).

As one can see, sovereignty is inalienable because it is of general will, and the sovereign is a collective entity that can only be represented by himself. This means that the greatest difficulty in exposing the general will is to show its relationship with the private ones. General will stems from private ones, though independent and rarely coincident. There is a nexus between authority and ordinary life. Common interest is not everyone's interest. It is everyone's and each one's interest while components of the collective body, exclusively as a member of the political body. An agreement between private and general will is impossible: the former tends to predilections; the latter, to equality. Natural impulse is egotistical; life in society imposes everyone equal patterns.

Sovereignty implies a non-contrastive will. If there is a Lord, there is no sovereign and the political body is destroyed. Rules for the power: 1) power can be transferred, never the general will; 2) any people's submission commitment ends the civil state; 3)authorities' orders must conform to general will, as long as this keeps silent, the refore sovereignty is inalienable.

Thus, sovereignty assumes total alienation of associated members, with all their rights, to the whole community. This is the synthesis of all the social contract clauses, for the official body (acting like a person) remains free, even towards the fundamental social pact, and does not acknowledge the State a limitless power, superior to moral and the right. In this sense, the political or sovereign body only exists due to the contract integrity, that is, as long as its integrity is not rocked. The contract integrity expresses the relationship between the political (a need to keep the contract) and the moral (the duty to obey a superior entity).

The crowd gathered in a body: it means the connection between duty and interest. Such connection is the anticipation of the" popular sovereignty" notion, when it is the basis for direct democracy, to which both the individual and the collective are fundamental players of the same reality. Here are Rousseau's words: "People's deputies, therefore, are not and cannot be their representatives; they are only their commissioners; cannot take any definite decision. Every law not confirmed by the people is null and void; it is no law at all." (Rousseau, 1973,p.114).

People's sovereign Will remains inalienable, that is, insuperable, for it is the result of all particulars' association; common power unable to affect its particulars without affecting itself. Such inalienable sovereignty, unique and legitimate is popular sovereignty. It is distinct from the representative sovereignty, criticized by Rousseau, as the following: "The English people think they are free, but are completely wrong; they are only free on the occasion of the election of Parliament's members; as soon as these are elected, people become slaves, nothing else." (1973,p.114).

In this sense, one can assure that the liberals of the XIX century were worried to guarantee individuals against State. Rousseau, on the other hand, believing in the general will, defends the State against a few usurpers of the State's power, for example, kings, as well as privileged classes. Awareness of the developed general will is directed to overcome private will. It is the consciousness of the general will overcoming the private one, thus preventing State's degeneration from emerging, and guaranteeing it against degenerated individuals. The State has to be the moral head of the social body, and answers as such. One understands how strong it is in Rousseau, the appreciation of both morality and collective consciousness. He advocates the absolute sovereignty as being solely popular sovereignty, unable to affect its own constitutive elements without affecting itself. Therefore, it is perfect and legitimate as an association of all particulars, without representing a power contrary to individual freedom. 
The absolute dimension of sovereignty has its grounds in the social pact: "Just like nature gives every man an absolute power over all its members, social pact grants the political entity, an absolute power over all of its own." (1973,p.115).

\section{Sovereignty in the "Discourse" and in the "Contract"}

In the Discourse "On the Origin and Fundamentals of Inequality among Men", from 1755, Rousseau undertakes an assessment of man and society in the "state of nature". According to him, the Discourse has the aim to expose, in a general idea, man's knowledge as the most important of all, so described in the First Part:

By depriving this Being so constituted, of all his supernatural gifts, and all artificial faculties to be acquired through long term progresses, just like he can obtain from nature, I see a less strong, agile animal, but together, better organized than all the others. (Rousseau,73,p.243).

Although Rousseau attempts to describe a former stage of civil society - the state of nature - according to his method and theory, he makes readers realize the forthcoming civil historic moment of modern humanity of collective civil organization, whose search for "perfectibility" (development) gave rise to inequality among men. Therefore, there would be two kinds of inequalities: natural or physical inequality, and moral, political inequality. Our text will give more focus on the latter, since Rousseau highlights in it, moral and psychological characteristics of men:

I conceive in human species, two kinds of inequalities: one that I will call natural or physical, established by nature, and consisting of differences in age, health, body strength, soul and spirit qualities; another, that can be called moral and political inequality, because it depends on a sort of convention, established or, at least authorized by men's consent.(Rousseau, 1973, p.241).

Before going on to psychological characteristics, we will let you know that by examining inequality roots, Rousseau admits mankind has undergone five stages of inequality. Because the condition keeps growing in each stage, the one of property would be the most harmful. For it is due to this irreparable evil, which turns men into weak or strong, that the loss of happiness, as well as of freedom would fall upon mankind and thus, causing complete inequality among individuals.

Despite that, we are interested in man's happiness condition in the state of nature. Under this condition, man is free, because this allows him to be happy, and not a slave of laws, work, or somebody else's subjection. Having said that, we draw the attention to the relationship between Rousseau's sovereignty (as exposed in The Contract) and the instinct of wish or desire, meaning "will' (as exposed in the Discourse on Inequality). Man, psychologically characterized by Rousseau, similar to animals, has the feeling of where the ideas stem from, making him perceive and feel. However, he is distinct from animals exactly by his capacity to desire and wish, thus constituting volitional acts in which, by means of language, his interests interact. Let us confirm this in the words of Bastide:

What distinguishes man from animals is, primarily, freedom; through it, man wishes and doesn't; desires and fears. Then, the capacity to move forward and retrograde; it is the cause of man's unhappiness, who did not know how to remain in the state of nature happiness. (Bastide, 1973, p .212)

One can conclude, therefore, that the state of nature is identified by the preponderance of man's instincts, whereas in the civil society state, reason is sufficient. Now, this freedom is the instrument that allows man to decide and give emphasis on his thoughts, materializing them into acts.

The state of nature, analyzed in the Discourse, as the term means, is a stage of human life in which man will not remain indefinitely; on the contrary, he passes from one moment to another. This implies new and different forms of social relationship. It is this moral/psychological aspect - volition, as a conscious act of the individual, which will be the basis for the development of Rousseau's general will and sovereignty in the civil society, as the maximum expression of people's clear and conscious participation. For, if individuals in modern civil society are able to establish their ethical norms of coexistence, as well as make their ideas determinant and sovereign, above a despot's private will, these being legislatively represented and identified, this was only possible due to the human liberty particularity in mankind's youthful age.

Will/freedom (in the state of nature) and general will/sovereignty (in civil society) can only be understood in Rousseau's thoughts, both, as the development of a moral consciousness, via philosophical anthropology.

Only this aspect distinguishes man from animal in the state of nature, despite the loss of happiness, man maintains this peculiarity by raising it to the sphere of collective life in civil society. The Social Contract rests on the idea of sovereignty, the constitution of a solid, modern, democratic and participatory life. With this aim, it seeks to clarify limitations that can recognize in itself the general will or the sovereignty as the power expressed in such will. 
Let us start by highlighting that, for well understanding such idea, it does not suffice to declare it the cornerstone of Rousseau's theory, or that general will is inalienable, non-transferrable, indivisible and absolute. Obviously, these are indispensable for its understanding. What we mean is that sovereignty is circumscribed; better, its origin is delimited by a historical and a philosophical field and, without recognizing its historical background, interpretation becomes incomplete. The year 1857 is the year of The Contract issuing, which means three decades before French Revolution; Rousseau's death occurred eleven years before the same Revolution. Historically, that period was pre-revolutionary to the events of 1789, with fierce popular battles for the end of the ancient régime, of decadence of religious absolutist institutions, a moment of intense criticism and people's rebellions, so that old monarchy could hear people's dissatisfactions. Rousseau is a son of such scenario. His work reflects a democratic revolutionary consciousness. Let us see what says Machado about this:

About Law is the title of chapter VI, which starts, by the way, with a clear proposition of the problem: if "by the social pact we brought existence and life to the political body, we will have to confer through legislation, movement and will to it". In fact, to the genetic description that gave us a safe view, though a bit static, anatomic of the political entity, one must add the exam of its physiology and active behavior. And the State lives and acts by the law. We should not lose ourselves about such purpose, in metaphysical ideas that, by declaring all justice comes from God, or still, there is a universal justice emerging from reason, do not define in its essence, what the law of State is. Now, it is mandatory to know that just the relationship resulting from the exposed by the general will, "when everybody decides on something towards everybody" for as it is a general deliberation matter, such as the will that states it, there we will have what can and should be called law. In other words, law that can never discriminate or particularize, is the expression of the conditions of civil association, just like they are established by the same people whom they will oblige. (Machado, 1973,p.17).

Sovereignty concept is ultimately, the scientific processing of such rebellions, whose ideas confirm the political philosophical project of French Revolution and the Enlightenment. Both the Enlightenment and Rousseau's sovereignty foundations materialize the clear consciousness applied by formulations, in the establishment of civil society.

\section{Conclusion}

From the exposed, one can infer about Rousseau and his work and sovereignty, a few observations that deserve to be highlighted: a) the sovereignty concept is prior to Rousseau. Several theoreticians of philosophy, law, among others (already mentioned along the text), have treated the concept. Religion itself, since ancient times (divine sovereignty) has characterized the aspect of absolute autonomy when meaning something or somebody sovereign; b) the Social Contract practically sums up all the philosopher's patiently matured thoughts, which favor the formulation of several fundamental ideas; c) Despite the great influence absorbed by Rousseau, from a protestant, evangelical conception (in which he had been educated in Geneva) to the influence of contractualists and encyclopedists the author surpasses his masters, by constructing his own concept of sovereignty. It is original, in that it is understood as the only ethical, political instrument capable of organizing collective life in civil society, under the aegis of moral equality; d) Another particularity of sovereignty, according to the thinker, is the fact that it can only exist under or in complete identity with General Volition. That is why sovereignty, general will and people are inseparable: one exists depending on the other's existence, in order to be put into practice; e) Rousseau advocates that Laws and the State have to necessarily express general will; f) General will is the absolute, inalienable, non-transferable supreme good, responsible for the guarantee of equality among men; g) finally, people's general, sovereign will is the condition sine qua non of freedom and happiness of man in modern, collective life, as well as the development of human sheer will, present in the state of nature.

\section{References}

ABBAGNANO, Nícola (2009). Dicionário de Filosofia. São Paulo: Martins Fontes.

BASTIDE, Paul Arbousse (1973). Introdução. In ROUSSEAU, Jean Jacques. Os Pensadores. São Paulo: Abril Cultural.

BOBBIO, Norberto (2010). Estado, Governo: por uma teoria geral da política. Rio de Janeiro: Paz e Terra.

BOBBIO, Norberto, MATTEUCCI, Nicola \& PASQUINO, Gianfranco (1995). Dicionário de Política. Distrito Federal: Editora da UNB, Vol. 2.

CHÂTELET, François, DUHAMEL, Olivier \& PISIER, Evelyne (2007). História das Ideais Políticas. Rio de Janeiro: Zahar. 
CHÂTELET, François, DUHAMEL, Olivier \& PISIER, Evelyne (1993). Dicionário das Obras Políticas. Rio de Janeiro: Civilização Brasileira.

FORTES, Luiz Roberto Salinas (1987). Rousseau: o mundo político como representação e vontade. In: Moraes, João Quartim de. Filosofia política. Campinas / Porto Alegre: L\&PM.

GRUPI, Luciano (2002). Tudo começou com Maquiavel. Porto Alegre: L\&PM.

MACHADO, Lourival Gomes (1973). In: ROUSSEAU, Jean Jacques. Os Pensadores. São Paulo: Abril Cultural.

ROUSSEAU, Jean Jacques. Discourse on the Origin of Inequality (2004). DoverPublicationsInc, New York.

ROUSSEAU, Jean Jacques. On The Social Contract (2003) Dover Publications Inc New York

ROUSSEAU, Jean Jacques (1998). The Social Contract. Hertfordshire: Wordsworth.

ROUSSEAU, Jean Jacques (1995). Meditations of a Solitary Walker. London: Penguin

ROUSSEAU, Jean Jacques. The Social Contract and the Discourses (1993).London: Everymans Library.

ROUSSEAU, Jean Jacques. (1973). Os Pensadores. São Paulo: Abril Cultural.

ROUSSEAU, Jean Jacques (1973). Do Contrato Social. In ROUSSEAU. Os Pensadores. São Paulo: Abril Cultural.

ROUSSEAU, Jean Jacques (1973). Discurso sobre a origem e os fundamentos da desigualdade entre os homens. In ROUSSEAU. Os Pensadores. São Paulo: Abril Cultural. 